\title{
Rare case of congenital anomaly in two different gestational ages: a case series
}

\author{
Lopamudra B. John*, Sendhil Coumary A, Seetesh Ghose
}

Department of Obstetrics \& Gynecology, Mahatma Gandhi Medical College and Research Institute, Pilliarkuppam, Pondicherry-607402, India

Received: 1 April 2013

Revised: 3 April 2013

Accepted: 14 April 2013

\section{*Correspondence:}

Dr. Lopamudra B. John,

E-mail: drlopamdpondy@yahoo.com

(C) 2013 John LB et al. This is an open-access article distributed under the terms of the Creative Commons Attribution License, which permits unrestricted use, distribution, and reproduction in any medium, provided the original work is properly cited.

\begin{abstract}
Acrania is a rare congenital anomaly involving faulty development of membranous flat bones of neurocalvarium. Commonest differential diagnosis is anencephaly. The first case was diagnosed in a second gravida at 13 weeks and terminated by vaginal misoprostol instillation. The second case was diagnosed only by scan at 32 weeks in an unbooked second gravida with previous LSCS. She underwent emergency LSCS for failed induction and a fresh stillborn baby of $1.9 \mathrm{~kg}$ was born.
\end{abstract}

Keywords: Acrania, Anencephaly

\section{INTRODUCTION}

Acrania is a rare, lethal congenital anomaly affecting the membranous flat bones of the neurocalvarium with complete but abnormal development of brain tissue. ${ }^{1,2}$ Also known as exencephaly, this condition is frequently associated with anencephaly though not always and isolated acrania is a rare entity. ${ }^{3}$

\section{CASE REPORT}

The first case is a 26 year old G2P1L1 at 13 weeks diagnosed with acrania by prenatal scan and referred to our institute for management. She was otherwise uncomplicated without any family history and an uneventful prior normal delivery at term. Ultrasound was done for confirmation and pregnancy was terminated by $400 \mu \mathrm{g}$ vaginal misoprostol.

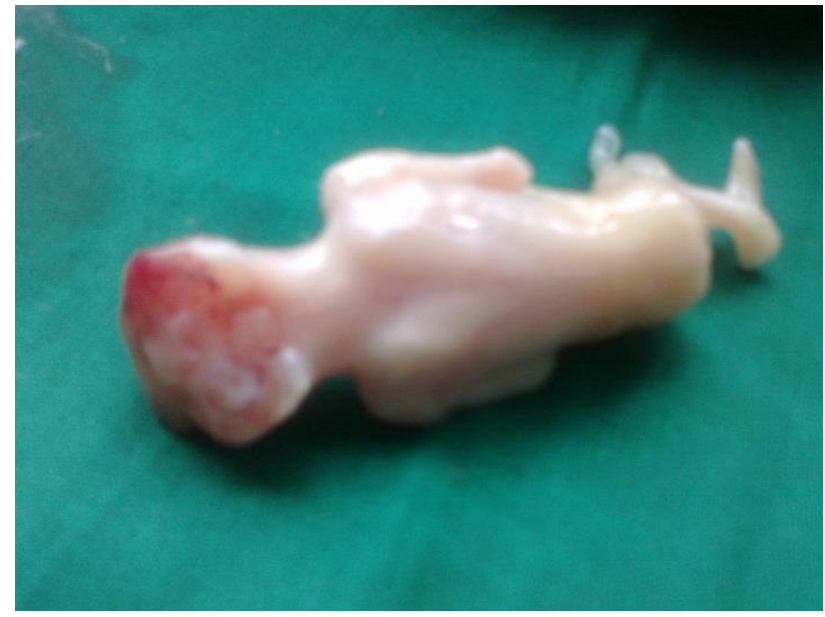

Figure 1: Acrania at 13 weeks. 


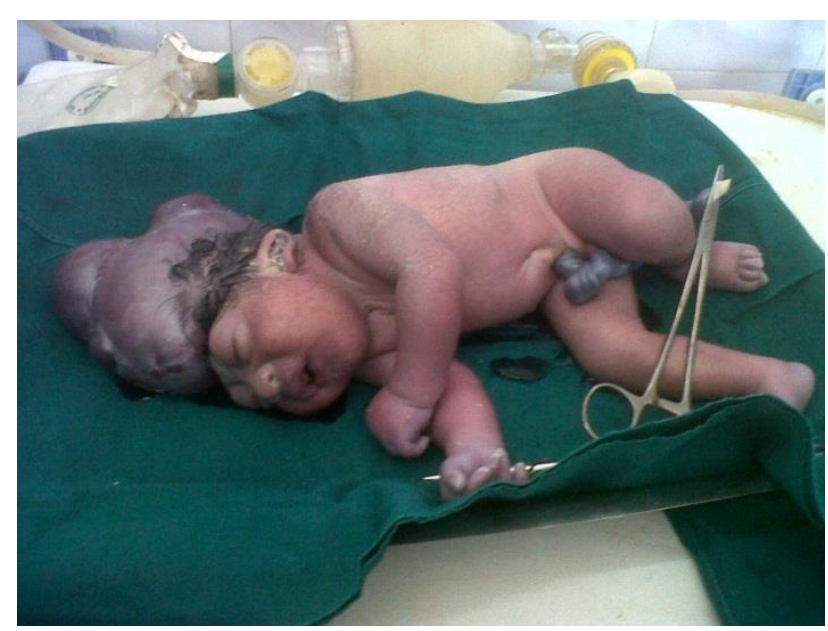

Figure 2: Acrania at 32 weeks.

The second case is a 28 year old G2P1L1 with previous LSCS at 32 weeks of gestation booked outside. On her first visit to our institute she was clinically suspected to be polyhydramnios, ultrasound was done and acrania of the foetus diagnosed. She did not have any other associated medical complications, no significant family history and her prior pregnancy was uneventful. Induction of labour was attempted with Foley's catheter followed by cerviprime gel which remained unsuccessful, extra amniotic saline infusion also failed. Emergency LSCS was done and a $1.9 \mathrm{~kg}$ fresh stillborn female baby delivered with no other obvious congenital anomalies.

\section{DISCUSSION}

Incidence of isolated acrania is unknown though it is $1: 10,000$ when associated with anencephaly. It begins at $4^{\text {th }}$ week of gestation when the anterior neuropore closes. Aetiology may be attributed to embryological fault or disruption by amniotic bands. It results from failure of migration of mesenchymal tissue under the calvarial ectoderm leading to absence of calvarial bones, muscles and dura mater whereas cerebellum, brainstem and cranial nerves are normal. The cerebellar tissue fails to differentiate into 2 hemispheres. ${ }^{4}$

Diagnosis can be made by prenatal ultrasound by 12 weeks by the absence of high echogenic calvarial rim surrounding the brain tissue. ${ }^{5}$ However, to differentiate this condition from anencephaly ultrasound at 15-16 weeks is required. ${ }^{4}$ Differential diagnosis is with anencephaly (absence of major portion of brain tissue), meroacrania (absence of all calvarial bones except occipital bone), encephalocoele (part of brain is intracranial) and mineralisation defects like hypophosphatasis and osteogenesis imperfect. ${ }^{6}$

This congenital anomaly is not compatible with life and hence when diagnosed antenatally subjects the obstetrician to the difficult task of counselling the expecting parents for termination of pregnancy. No evidence regarding it's recurrence is available and neither does it increase the chance of open neural tube defect in the future. ${ }^{3}$

Funding: No funding sources

Competing interests: There are no competing interests to declare

Ethical approval: Not required

\section{REFERENCES}

1. Mannes EJ, Gelin ES, Hobbins JC, et al. Sonographic demonstration of foetal acrania. AJR 1982;139:181.

2. Romero R, Pilu G, Jeanty J, et al. Prenatal diagnosis of Congenital Anomnalies. Appleton and Lange, Norwalk, Connectitut; 1988:75-6.

3. Tae Hee Kwon, Jim King, Philippe Jeanty, et al. Acrania: a review of 13 cases. Available at www.thefoetus.net. Accessed 25 January 2013.

4. Sabat SB, Kulkarni S, Sangneria MA. Acrania without Anencephaly. The Internet Journal of Gynaecology and Obstetrics 2009;11:1.

5. Rankine M, Hafner E, Schuchter K, Philipp K. Ultrasound and Endoscopic Image of Exencephaly (Acrania) in the $12^{\text {th }}$ week of pregnancy. Z Geburtshilfe Neonatol;2000;204:236-8.

6. Bianca S, Ingegnosi C, Auditore S, Bartoloni G, et al. Prenatal and Postnatal findings of Acrania. Arch Gynecol Obstet 2005;271:256-8.

DOI: $10.5455 / 2320-1770$. ijrcog20130630

Cite this article as: John LB, Sendhil CA, Ghose

$\mathrm{S}$. Rare case of congenital anomaly in two different gestational ages: a case series. Int J Reprod Contracept Obstet Gynecol 2013;2:240-1. 